Makale Gönderim Tarihi: 21.12.2021

Makale Kabul Tarihi: 23.12.2021

Araştırma Makalesi

\title{
Siyaset Felsefesinin Temel Kavramları Üzerine Bir Değerlendirme
}

\section{Özkan KERIMOĞLU1}

\section{Öz}

Bu çalışmamızın amacı, bireyin ve toplumun iyi yaşam ve mutluluğa ulaşması için, ideal siyaset anlayışının benimsediği temel ilkeleri belirlemek ve öz değerlendirmelerde bulunmaktır. İnsan, doğası gereği sosyal bir varlıktır ve yaşamını sürdürebilmesi için çeşitli ihtiyaçları vardır. Sosyal çevre ve burada yaşamak, bu ihtiyaçların temini için olması gereken uygun ortamdır.

Siyaset felsefesinin önemsediği temel kavramları adalet, özgürlük, eşitlik, hukuk, hak, yasa, birey, sivil toplum diye siralayabiliriz. Bunlar mutlu birey, huzurlu toplum ve iyi bir yaşam için olması gereken değerlerdir.

Anahtar Kelimeler: Adalet, eşitlik, birey, özgürlük, hukuk.

\section{An Assesment About Basic Principles Of Political Philosophy}

\section{Abstract}

The purpose of this study is to determine the basic principles adopted by the understanding of ideal politics and to make self-evaluations for a better life and happiness for the individual and society. Human beings are social creatures by nature and they have various needs in order to survive. The social environment and living in this environment is the appropriate place to be in order to meet these needs.

Atıf/Reference: Özkan Kerimoğlu, "Siyaset Felsefesinin Temel Kavramları Üzerine Bir Değerlendirme", Farabi Felsefe ve Din Bilimleri Dergisi, S.1, 2020, 20-46.

1 Dr., İstanbul, Silivri Yunus Emre İmam Hatip Ortaokulu Müdürü 
We can list the basic concepts of political philosophy as justice, freedom, equality, law, rights, individuals and civil society. These are the essential values for a happy individual, a peaceful society and a good life.

Key Words: Justice, equality, individual, freedom, law.

\section{Giriş}

İnsan, toplumsal bir varlık olarak yaratılmıştır. Toplumsal yaşantı ve birlikteliğin sürdürülebilmesi için, toplumdaki ilişkileri düzenleyen ortak davranış kurallarının belirlenmesi ve toplum üyelerinin bu kurallara uymasını sağlama gereği vardır. Bu gereksinim, bir yapılanma, örgütlenme ve kurumsallaşma nedeni olmaktadır. ${ }^{2}$ Ayrıca düşünen ve araştıran her insan, kendisini mutlu edecek iyi bir hayatı, iyi bir toplumu ve iyi bir yönetim şeklini elde etmek için uğraş vermiştir, vermektedir ve vermeye de devam edecektir. Bu ve benzeri gerekçeler, arayışlar ve soruların cevabı olarak birtakım oluşumlar ve bilim dalları ortaya çıkmıştır ki bunlardan bir tanesi de siyaset felsefesidir. Siyaset felsefesinin tanımı, konusu, diğer ilim dalları ile ilişkisi gibi konulara geçmeden önce siyaset ve felsefe kavramları üzerinde durmamız, faydadan hali değildir.

Kaynaklar incelenip, filozofların eserleri tarandığında görülecektir ki felsefenin tanımı konusunda ortak bir tutum söz konusu değildir. Her filozof felsefeyi, benimsediği felsefi görüş, felsefi sistem ve kişisel birikim ve kabiliyeti doğrultusunda, yaşadığı çağın gereksinimlerini de göz önünde bulundurarak tanımlamaya çalışmıştır.

Felsefe, Eski Yunancada "sevmek" anlamina gelen philein/philo ile "bilginlik" ya da "bilgelik" anlamına gelen sophia sözcüklerinin philosophia biçiminde birleştirilmesiyle oluşturulmuş; sözlük anlamıyla "bilgelik sevgisi", "bilgi severlik" ya da "bilgi sevdası" gibi anlamlar taşıyan, içindeki tüm öğeleriyle birlikte bütün bir disipline adını veren terimdir. ${ }^{3}$ En

2 Esat Çam, Siyaset Bilimine Giriş, İstanbul: Güryay Matbaacılık, 1977, 11.

3 Mahmut Kaya, "Felsefe", Türkiye Diyanet Vakfı İslam Ansiklopedisi, İstanbul, TDV Yayınları, 1995, 12/ 311; Sarp Erk Ulaş, "Felsefe" Felsefe Sözlüğü, Ankara: Bilim ve Sanat Yayınları, 2002, 532; Mahmut Kaya, "Felsefe", Türkiye Diyanet Vakfı İslam Ansiklopedisi, İstanbul: TDV Yayınları, 1995, 12/ 311; H. Ömer Özden-Osman Elmalı, İlkçağ Felsefesi Tarihi, İstanbul: Bilge Kültür Sanat Yayıncılık, 2018, 17; Abdülkadir Çüçen, Felsefeye Giriş, İstanbul: Asa Yayınları, 2001, 41; Süleyman Hayri Bolay, "Felsefe”, 
genel anlamıyla felsefe, "saltık gerçeklik" ile "saltık doğruluk"un en son anlamdaki değişmez ilkeleri üstüne düşünen, bütün bir varlık alanını her yönüyle araştıran, her durumda en temel ilkelere, doğru bilgilere, iyi ve güzel yaşama ulaşmaya yönelik olarak yürütülen ussal ve eleştirel sorgulama biçimidir. ${ }^{4} \mathrm{Bu}$ tanımdan da anlaşıldığı gibi felsefe, evreni içinde bulunan her şey ile birlikte anlamaya çalışmak, insan bilgisinin kökenlerini, kaynağını ve temellerini araştırmak, aynı şekilde doğru bilgiyi yanlış bilgiden ayırt edebilmek için birtakım yöntemler ve ölçütler geliştirmek, insanın tanrısal yönelimleri ile doğa ötesi bağlanımları karşısındaki konumunu tanımlamak ve iyi bir yaşam yolunda mutluluğa ulaşmak için nelerin yapılması gerektiği sorusu bağlamında, bütün insan eylemlerinin değerlendirilmesine yönelik köklü bir araştırmaya karşılık gelen soruşturmalar bütünüdür. $O$ halde felsefe için, ilkece üzerine düşünülmesi olanaklı bütün her şeyi düşünen, var olan her şeyi bütün yönleriyle sorgulayan alabildiğine çok araştırmalar bütünü olarak, hem bilginin hem de yaşam bilgeliğinin peşinde koşma etkinliğidir diyebiliriz.

Çalışmamızın içeriği gereği ilgilendiğimiz diğer kavram ise siyasettir. Siyaset terimi, Arapça kökenli bir sözcük olup Türkçeye geçmiştir. Bu dilde "siyasa" şeklinde kullanılmaktadır. Sws veya sasa kökünden gelen siyasa kelimesi “idare etmek, işleri düzene koymak (tedbir), eğitmek, yetiştirmek" ${ }^{\prime \prime}$ gibi anlamlara gelmektedir. Orijinal olarak bu kelime önce bedevi toplumlarda hayvanların, özellikle de atların ve develerin, terbiye edilmesi ve yetiştirilmesi için kullanılmıştır. ${ }^{6}$ İngilizcedeki karşılığı "politics" olan siyaset kavramı Yunancada şehir anlamına gelen "polis" kelimesinden türemiştir ki şehirle ilgili işler, devlet idaresi ile ilgili olan, devlete ait işler anlamına gelmektedir.7 Sözcük anlamı olarak farklı dillerde benzer anlamları ihtiva eden siyaset kavramının detaylandırılmış tariflerine bakınca farklı tanımlarla karşılaştığımızı gözlemliyoruz. Siyaset kavramı hem günlük konuşma dilinde hem de toplumsal bilimler alanında farklı anlamlarda kullanılmaktadır. Toplumun işlerini

Felsefi Doktrinler ve Terimler Sözlüğü, Ankara: Akçă̆ Yayınları, 1995, 140; H. Ömer Özden, İslam Felsefesi Tarihi, İstanbul, Bilge Kültür Sanat Yayıncılık, 2017, 17.

4 Alfred Weber, Felsefe Tarihi, çev. H. Vehbi Eralp, İstanbul: Sosyal Yayınları, 1991, 1; Ulaş, "Felsefe" Felsefe Sözlü̈̆̈̈̈, 532.

5 Dursun, Siyaset Bilimi, İstanbul: Beta Yayıncılık, 2002, 25; Süleyman Hayri Bolay, "Siyaset Felsefesi" Felsefi Doktrinler ve Terimler Sözlüğ̈̈, 366; Hızır Murat Köse, "Siyaset", Türkiye Diyanet Vakfı İslam Ansiklopedisi, İstanbul: TDV Yayınları, 2009, 37/294; Ahmet Taner Kışlalı, Siyaset Bilimi, Ankara: AÜ Basın Yayın Yüksek Okulu Yayınları, 1987, 3.

6 Dursun, Siyaset Bilimi, 25; Kışlalı, Siyaset Bilimi, 3.

7 Bolay, "Siyaset Felsefesi” Felsefi Doktrinler ve Terimler Sözlü̆̆̈̈, 366; Kışlalı, Siyaset Bilimi 3; Atilla Yayla, Siyaset Teorisine Giriş, Ankara: Siyasal Yayınevi, 2004, 1. 
üzerine alma, yürütme, yönetme işi, insan topluluklarını yönetme sanatı şeklinde tanımlanan siyaset kavramı, elbette ki önceki dönemlerde bugünkü demokratik politika gibi herkesi kapsama, çoğulcu ve yarışmacı olma vasıflarından uzaktı. İlerleyen zaman içinde politikanın kapsamı, tarzı ve vasıfları da değişti ve politika, beşeri faaliyetlerin meşru ve gerekli bir türü olarak kabul edilir hale geldi. Şehirlerin ve insanların yönetimi anlamında siyaset, onların refahını artırmak için belirli bir yöntemle onları yönetme sanatı olarak da ifade edilebilir. ${ }^{8}$

Bugüne kadar yapılan tanımların her biri politikanın değişik yönlerini öne çıkarmış veya tanımı yapanların ideolojik ve değerlerle ilgili konumunu sergilemiştir. Felsefede olduğu gibi siyasetin tanımı konusunda da herkesi tatmin eden ve herkesin üzerinde ittifak ettiği bir tanım ortaya çıkmamıştır. Siyasetin kendisi de, tanımı da halen çeşitli bakımlardan tartışılmaktadır. Tanımı yanında, siyasetin bir bilim mi, sanat mı yoksa bildiğimiz anlamda bir hayat gerçeği mi olduğu da siyaset bilimi edebiyatında tartışılan bir konudur. ${ }^{9}$

Politika (siyaset) nedir? Sorusuna eski çağlardan bugüne kadar verilen cevapların çeşitliliğinden yukarıda söz etmiştik. Şimdi bu farklı ve çeşitli tanımlardan çalışmamıza ışık tutacak olanlarından birkaçını sunmaya çalışalım. Bülent Daver siyaseti “Ülke, devlet ve insan yönetimi” ${ }^{10}$, P. H. Merkle “İnsanın kendi toplumsal görüşlerine göre içinde yaşadı̆̆ı topluma bir düzen verme süreci"11, İmam Gazali ise "beşeriyeti 1slah ile dünya ve ahrette selamete ulaştıracak doğru yolu gösteren bir sanat"12 olarak tanımlamaktadır. Gazali, bu tanımıyla dört mertebede ele aldığı siyaseti, sanatların en şereflisi olarak tasvir ederek, bu sanatın diğer sanat dallarının aramadığı kemalatı gerektirdiğini ve bu sanatın sahibinin diğer sanatları kendine hizmet ettirdiğini ifade etmektedir. ${ }^{13}$ Ünlü Türk düşünürü Farabi ise siyaseti mutlak siyaset ve cahiliye siyaseti diye sınıflandırdıktan sonra saadetin ne olduğunu araştıran ilme "medeni ilim (siyaset)" demektedir. Farabi'ye göre siyaset, insanın elde etmek zorunda olduğu olgunluğun ne ve nasıl olduğunu, ona ulaştıran vasıtaları elde etmede yararlı olacak şeylerin neler olduğunu ve olgunluğun yolunu tıkayan engellerin nelerden ibaret olduğunu, her birinin

\footnotetext{
8 Dursun, Siyaset Bilimi, 25.

9 Yayla, Siyaset Teorisine Giriş, 2.

10 Kışlalı, Siyaset Bilimi, 3; Çüçen, Felsefeye Giriş, 315.

11 Çam, Siyaset Bilimine Giriş, 19.

12 İmam Gazali, İhyau Ulumi'd-Din, çev. Ahmed Serdaroğlu, İstanbul: Bedir Yayınevi, 1974, 1/40.

13 Gazali, İhyau Ulumi'd-Din, 1/40.
} 
neden ve niçin mevcut oldukların bildiren ve ayırt eden ilimdir. ${ }^{14}$ Siyaset, Aristo'nun ifadesi ile "Vatandaşların toplumu ilgilendiren işlerle ilgili olarak yaptığı her şey"15dir. Bir başka tanıma göre ise genel anlamda siyaset; “devleti her alanda idare edecek kuralların bütünü"16 olarak tanımlanabileceği gibi, "iktidarın ele geçirilmesine yönelik eylemlerin tümü"17 diye tanımlamak da mümkündür.

Verilen bu tanımlar ele alındığında siyasetin tamamen farklı ve birbirine zit iki ayrı yönünün olduğunu görürüz. Bir görüşe göre siyaset (politika) toplumda yaşayan insanlar arasında bir çatışma, bir mücadele ve kavgadır. Karşıt temel görüşü temsil eden düşünürlere göre ise politikanın amacı her şeyden önce toplumda bütünlüğü sağlamak, özel çıkarlara karşı koyarak genel yararı ve insanların ortak iyiliğini gerçekleştirecek adımları atmaktır. Her iki anlayışta amaç ve hedef tamamen farklıdır. Birisinde bir iktidar hırsı, pragmatik bir hissiyat söz konusu iken, diğer anlayışta daha bütüncül ve pozitif bir hizmet etme tasavvuru hakimdir.

$\mathrm{Bu}$ tanımlamalarda akla siyasetin kaynağı nedir? Siyaset neden doğmuştur? sorusu gelmektedir. Şüphesiz bu soruya verilen cevaplarda, siyasetin oluştuğu fiziki, biyolojik, ekonomik, toplumsal ve kültürel çevrelerin etkisinden, katkısından söz etmemek objektif ve rasyonel bir bakışın ürünü olmaz. Birçok yazar siyasetin tarifinin çeşitli olmasının kaynağında, insanların fıtraten birbirlerinden farklı olmasının önemli bir etken olduğu konusunda hemfikirdir.

Bu kanaate sahip olanların ileri sürdükleri gerekçeleri şu şekilde açılayabiliriz. İnsanlar, dini inanış, dünya görüşü, hayat tarzı, menfaat algılaması, kıyafet kodu, estetik anlayışı, değer tercihleri ve benzeri bakımlardan birbirinden farklıdır. Bu farklılıklar, insanlar arasında anlaşmazlıkları ve ihtilafları doğurur. Bu anlaşmazlıkları çözmenin değişik yolları vardır. Bu çözüm yollarından biri de siyasettir. Şiddeti dışlayan, müzakere ve uzlaşıya açık bir siyaset anlayışı söz konusu ise bu problemlerin çözümünde siyaset, çözüm araçlarının en önemli ve etkilisi olarak ortaya çıkar. Farklı yaratılışlara, ekonomik ve sosyal durumlara sahip insanlar arasındaki bu farklılık politikanın temelini oluşturur. ${ }^{18}$ Aynı şekilde insanların toplu halde

14 Farabi, Mehmed b. Tarhan b. Uzluğ, Kitabu Tahsil es-Saade, Haydarabad:, H.1345, 15-16; Bayraktar Bayraklı, Fârâbî'de Devlet Felsefesi, İstanbul: Doğuş Yayınları, 1983, 14-15.

15 Bolay, Felsefi Doktrinler ve Terimler Sözlüğ̈̈, 366.

16 Süleyman Hayri Bolay, Felsefeye Giriş, Ankara: Akçağ Yayınları, 2002, 221.

17 Ali Öztekin, Siyaset Bilimine Giriş, Ankara: Siyasal Kitabevi, 2003,1.

18 Münci Kapani, Politika Bilimine Giriş, Ankara: Bilgi Yayınevi, 2002, 17-18; Yayla, Siyaset Teorisine Giriş, 5; Dursun, Siyaset Bilimi, 32. 
yaşamaları da bir diğer faktör olarak dikkatlere sunulmaktadır. Eğer her birey tek başına ve bir başka bireyle etkileşim halinde olmaksızın yaşamını sürdürebilseydi, siyaset de söz konusu olmazdı; bu bakımdan siyaset, ortak yaşamın bir sonucudur. ${ }^{19}$ Çünkü her toplum öncelikle varlığını sürdürmek, ortak sorunlarını çözmek, kamusal hizmetleri görmek, ortak değerler üretmek ve bunların bölüşümünü gerçekleştirmek amacıyla özel bir örgütlenmeye ihtiyaç duyar. İster geleneksel, ister modern ve gelişmiş bir toplum olsun bu tür kamusal ihtiyaçlar için bir yönetim örgütü geliştirmek zorundadır. Şehir devletleri, feodal prenslikler, imparatorluklar, ulus-devletler, dünya siyaset sistemi bu amaçla gerçekleştirilen organizasyonlardır. Bu organizasyonların adı ne olursa olsun biz genel bir adlandırma ile buna "siyasal sistem" 20 diyebiliriz.

Siyasetin tanımı üzerinde herkesin ittifak ettiği bir tanımın bulunmadığını belirtmiş ve her tanımın veya yaklaşımın siyasal gerçeklik dediğimiz toplumsal hayatın bir yanına vurgu yaptığını ve farklı bir özelliği öne çıkardığını ifade etmiştik. Bunlara rağmen siyaseti, toplumun tümünü ilgilendiren ilişkileri son aşamada meşru zora dayanarak düzenleyen eylemler bütünü olarak tanımlayanlar da bulunmaktadır. ${ }^{21}$

\section{Siyasetle İlgili Bazı Kavramlar}

Siyasi olgular, yapılar ve olaylar birkaç alanda ele alınıp incelenebilmektedirler. Bunları dört başlık altında toplayabiliriz.

Siyaset Teorisi: Siyaset teorisi, siyasileri siyasi davranış ve toplumsal sorunlar konusunda motive eden düşünce ve teorileri içerir. Siyasi düşünce içinde insanların birbirlerinin siyasi davranışlarını açıklama ve değerlendirme aracı olarak kullandıkları teoriler ve değerlerle, bu davranışları kontrol altına almak için kullandıkları mekanizmalar vardır. Siyasal düşüncenin merkezi fikir ve doktrinlerinin analitik incelemesini içeren siyaset teorisi, devlet, hukuk, hükümet, temsil, seçim gibi kurumların yanında adalet, özgürlük, eşitlik gibi etik veya ahlaki sorularla da ilgilenmektedir. Karşılaştırmalı ve açıklayıcı bir daldır. Tipik örnekleri anayasa tarihi ve anayasal, kurumsal analizlerdir. ${ }^{22}$

19 Dursun, Siyaset Bilimi, 31.

20 Dursun, Siyaset Bilimi, 33.

21 Dursun, Siyaset Bilimi, 33.

22 Andrew Heywood, Siyasetin Temel Kavramları, çev. Hayrettin Özler, Ankara: Adres Yayınları, 1.Basım, 2012, 153; Yayla, Siyaset Teorisine Giriş, 8. 
Siyaset Bilimi: Siyaset bilimini, siyasal otorite ile ilgili kurumların ve bu kurumların oluşmasında ve işlemesinde rol oynayan davranışların bilimi olarak tanımlayabiliriz. Siyaset bilimi, siyasi olanla ilgilidir. Adından da anlaşılacağı gibi, bilim olma iddiası bu dalın baskın özelliğidir. Akademik bir disiplin olarak siyaset bilimi, iktisat ve sosyoloji gibi dalların sağladığı bilgi ve tekniklerden de yararlanarak, siyasi bakımdan önem taşıyan olay ve eylemleri “bilimsel yöntemlerle" analiz etmeye çalışır. ${ }^{23}$ Siyaset bilimi, başta devlet olmak üzere siyasal kurumları, siyasal rejimleri sistemli bir şekilde ve herhangi bir değer yargısında bulunmaksızın, sırf açıklayıcı ve betimleyici bir tarzda inceleyip problemleri tespit eden bilim dalıdır. Siyaset bilimi, diğer bilimler gibi, siyasette olanı inceler, açıklar ve yasalarını bulmaya çalışır. ${ }^{24}$ Buna göre ahlak ve felsefeden bağımsız olarak olması gerekeni değil var olanı nesnel bir biçimde inceleyen siyaset biliminin konusu devlet, devletin kuruluşu, devletin temel işlevleri, amaçları, kurumları, vatandaşlarla ilişkileri; iktidar, güç ve otoriteye ilişkin davranışlar, oluşumlar, faaliyetler, kurumlar ve bunlarla olan ilişkilerdir diyebiliriz. ${ }^{25}$

Siyasi Düşünce: Siyasi düşünce ifadesi, siyaset felsefesi ve siyaset bilimi kavramlarından daha geniş bir alanı ifade eder. Siyasi düşünce, herhangi bir inancın, kanaatin veya mitosun açıklanması ya da savunusudur. İnsan topluluğunun olduğu hemen her yerde bir siyasi düşünceden bahsetmek mümkündür. Her siyaset felsefesi, siyasi bir düşüncedir ancak her siyasi düşünce siyaset felsefesi değildir. Siyasi düşünce, siyasete yönelik spesifik bir tutumu amaç edinen, insanlığın tarihi kadar eski bir düşünce türüdür. ${ }^{26}$

Siyasi Teoloji: Siyasi teoloji ise, doğruluğu peşinen kabul edilen kutsala dayanılarak temellendirilen siyasal düşüncedir. Yani, ilahi bir vahiyde temellendirilen siyasal öğretilere ilişkin bir araştırmadır. ${ }^{27}$

\section{Siyaset Felsefesi ve İlgili Kavramlar}

23 Heywood, Siyasetin Temel Kavramları;147-148; Kışlalı, Siyaset Bilimi, 4; Yayla, 9.

24 Ahmet Arslan, Felsefeye Giriş, Ankara: Vadi Yayınları, 1996, 154; Çüçen, Felsefeye Giriş, 316; Kışlalı, Siyaset Bilimi, 5; Dursun, Siyaset Bilimi, 67; Çam, Siyaset Bilimine Giriş, 11.

25 Dursun, Siyaset Bilimi, 69; Öztekin, Siyaset Bilimine Giriş, 3.

26 Leo Straus, "Siyaset Felsefesi Nedir?" Siyasi Hermenötik, çev. Burhanettin Tatar, Samsun 2000, 16; Şenol Korkut, Farabi'nin Siyaset Felsefesi, Ankara: Atlas Yayınları, 1.Basım, 2015, 24; Neşet Toku, Siyaset Felsefesine Giriş, İstanbul: Kaknüs Yayınları, 2005, 11.

27 Zerrin Kurtoğlu, İslam Düşüncesinin Siyasal Ufku, İstanbul İletişim Yayınları, 1999, 52; Korkut, Farabi'nin Siyaset Felsefesi, 25; Toku, Siyaset Felsefesine Giriş, 11. 
Siyasetle ilgili terimlerin tanımlarına yer verdikten sonra siyaset felsefesi nedir? Siyaset felsefesi hangi sorularla ilgilenir? Siyaset felsefesinin temel kavramları nelerdir? Siyasetin gerekliliği var mıdır? gibi problemleri incelemeye çalışacağız.

İnsanlık tarihinde ne kadar geriye gidilirse gidilsin, insanların ilk ortaya çıktığı andan itibaren toplum halinde yaşadıkları bir realitedir. O halde insanların aile, boy, klan, kabile gibi küçük toplumsal gruplar, örgütlenmeler içinde de olsa her zaman bir toplumda yaşadıkları ve başka insanlarla ilişki içinde olduklarını kabul etmek doğru bir yaklaşım olacaktır. Ancak bu bir arada yaşayışta bazı ahlaki kurallara uyulması zorunluluğu olmuş, insanlar yaşadıkları toplumun belirlediği ahlak kuralları tarafından yönlendirilmişlerdir. İlerleyen süreçte insanlık, doğal-ahlaki toplum halinden, hukuki-siyasal toplumlara geçmiştir. ${ }^{28}$ Buna göre hukuki-siyasal teşkilat, üyelerinin belli bir egemen gücün yönetimi altında birbirleriyle hukuki ilişkiye girdikleri, bu egemen güç tarafından çıkarılan yasalara uymak suretiyle yaşadıkları toplum biçimidir. İşte insanların egemen güç yani devletin yönetimi altında, devletin çıkardığı yasalara, kurallara uygun olarak yaşamak durumundan doğan olayları siyasal olaylar olarak tanımlayabiliriz. Öyleyse siyaset felsefesini, “aynı politik otoriteye, aynı yasaya itaat eden insanların meydana getirdiği siyasal topluluğu konu alan felsefi bir inceleme dalı"29 olarak adlandırılabilir.

İnsanlar, felsefeyle tanıştıktan sonra iyi hayat nedir? İyi bir hayat nasıl elde edilir? İyi bir hayat için gerekli olan iyi bir toplum, iyi bir devlet nasıl kurulur? gibi sorularla, hem ahlaki, hem de siyasi bir toplumun nasıl kurulabileceğini sorgulamışlardır. Bu sorular, düşünen, merak eden, araştıran rasyonel insanın sorularıdır. Siyaset felsefesi, siyasi eylem tekniğini yani iktidarın kaynağını, iktidarın kazanılışını ve elde tutulmasını, fertle devlet arasındaki ilişkileri ele alır. Gelecekte toplumların nasıl idare edilmesi gerektiğini ortaya koyabilmek için onların dününü ve bugününü de inceler. Siyaset felsefesi iktidarın kaynağı nedir?, devletin işlevi ve sorumluluğu nelerdir?, en iyi yönetim şekli hangisidir? gibi sorular üzerinde fikir üretir. ${ }^{30}$

Buradan şunu anlamaktayız ki siyaset felsefesinin özgün ilgi alanını, insan doğasına uygun ve insanı mutlu etmesi mümkün olan iyi bir siyasal yaşama biçiminin nasıl olması gerektiği hususu oluşturmaktadır.

\footnotetext{
28 Arslan, Felsefeye Giriş, 151.

Arslan, Felsefeye Giriş, 151.

30 Bolay, "Siyaset Felsefesi" Felsefi Doktrinler ve Terimler Sözlüğ̈̈, 366; Çüçen, Felsefeye Giriş, 316.
} 
Bütün bunlardan sonra siyaset felsefesinin en genel anlamda bir tanımını yapacak olursak şunları söylememiz mümkündür: Siyaset felsefesi, bir bütün olarak siyasetin özünü, doğasını, amaçlarını, kapsamını, içeriğini araştıran ve devletin yapısı başta olmak üzere devletin ödevlerini ve değerini felsefeye özgü yöntemlerle irdeleyen bir felsefe disiplinidir. Ayrıca siyaset felsefesi, günümüzde var olan ya da geçmişte var olmuş devlet biçimlerini, yönetim düzenlerini bölümleyen, devlet adamında aranması gereken nitelikleri ve sorumlulukları soruşturan, birey ile devlet ya da siyasal otorite arasındaki ilişkiyi siyasal yaşamın temel konuları özgürlükler ve sorumluluklar açısından çözümleyip, adalet, özgürlük, özel mülkiyet, baskı, eşitlik, insan hakları gibi çok temel kavramların anlamlarını açıklığa kavuşturan bir değer alanıdır. ${ }^{31}$ Anlaşılmaktadır ki siyaset felsefesi, toplumsal ve siyasal hayatla ilgili problemlere bir takım çözümler bulmak üzere ortaya çıkan düşünsel bir formdur. Bu düşünsel formda hedeflenen, insani-toplumsal düzenin nasıl olması gerektiğine yönelik teorik bir zemin hazırlamaktır. ${ }^{32}$ Siyasetin problemlerini, siyasi sistemleri, siyasal varlıklar olarak tanımlanan insanların belli bir siyasi sistem içindeki davranışlarını felsefeye özgü yöntemlerle ele alıp araştıran siyaset felsefesi, sosyal bir varlık olan insan için aydınlatıcı ve çözümleyici bir felsefe dalıdır diyebiliriz. ${ }^{33}$ Siyaset felsefesi üzerine yapılan bu öz açıklamadan sonra, amaç ve ilgilendiği konular itibariyle yakın bir disiplin olan ahlak felsefesi ile ilişkisine bakabiliriz.

\section{Siyaset Felsefesi-Ahlak Felsefesi İlişkisi}

Siyaset felsefesinin özgün ilgi alanını, insan doğasına uygun ve insanı mutlu etmesi mümkün olan iyi bir siyasal yaşama biçiminin nasıl olması gerektiği hususu oluşturmaktadır. Bu bağlamda siyaset felsefesi, ahlak felsefesine benzemektedir; hatta bazılarına göre o ahlak felsefesinin bir dalıdır. Eğer ahlak felsefesini “insan için genel olarak iyi hayatın ne olduğunu araştıran ve buna bağlı olarak insanların nasıl yaşaması ve davranması gerektiğini” belirlemeye çalışan bir disiplin olarak tanımlarsak, siyaset felsefesinin de aradığ 1 şeyin bundan farklı olmadı̆̆ını ifade edebiliriz. “İnsan için siyasal iyi nedir? İnsanın bu siyasal iyiyi gerçekleştirmek

\footnotetext{
31 Ulaş, "Siyaset Felsefesi", Felsefe Sözlüğ̈̈, 1308.

32 Toku. Siyaset Felsefesine Giriş, 9; Neşet, Toku. Johne Locke ve Siyaset Felsefesi, Ankara: Liberte Yayınları, $2003,1$.

33 Ahmet Cevizci, "Siyaset Felsefesi”, Paradigma Felsefe Sözlü̆̆̈̈̈, 852; Yayla, Siyaset Teorisine Giriş, 8.
} 
için ne yapması gerekir?" şeklindeki soru siyaset felsefesinin hedefini daha iyi anlatabilir. ${ }^{34} \mathrm{Bu}$, siyasete ahlak açısından bakılması ve onun ahlak açısından değerlendirilmesidir.

Buna mukabil ahlakı, siyasetin bir alt dalı, dolayısıyla ahlak felsefesini siyaset felsefesinin bir parçası olarak görmek de mümkündür. Bu bakış açısının benimseyicilerine göre, iyi insan hayatı, ancak iyi bir siyasal-toplumsal örgütlenme içinde mümkün olabilir. Erdemli bir toplum, erdemli bir siyasal yönetim, adil bir hukuk düzeni mutlu bir kişisel hayat için zorunludur. Toplumsal-siyasal örgütlenme, sadece bireysel hayatın mümkün olması ve devam ettirilmesi için değil, aynı zamanda onun kalitesinin iyileştirilmesi, niteliğinin yükseltilmesi için de zorunludur. Bu görüşü savunanların başında Yunan dünyasından Platon ve Aristoteles, İslam dünyasında Farabi, modern felsefede de Karl Marks sayılabilir. ${ }^{35} \mathrm{O}$ halde bu ikinci gruptakiler de ahlaka siyaset açısından bakmakta ve onu siyaset açısından değerlendirmektedirler.

Görülüyor ki hangi bakış açısı benimsenirse benimsensin, siyasetin ahlakla, siyaset felsefesinin de ahlak felsefesi ile sıkı ilişkiler içinde olduğu anlaşılmaktadır. Çünkü bu iki disiplin, değer felsefesinin sınırlarındadır. Bunun da kaynağında her ikisinin de insani iyi ve mutluluk sorunu ve iyi yaşama sorunu ile ilgili konuları ele almaları bu ele aldıkları konulara bireysel davranışlar-siyasal kurumlar salt açıklayıcı ve betimleyici bir tarzda yanaşmakla yetinmeyip, onlar hakkında değer yargılarında bulunmaları olgusu yatmaktadır.

Ahlak felsefesini genel anlamıla "iyi” nin iyi olanın, iyi davranışların doğasını, özünü ve kaynaklarını araştıran, "İnsan için iyi bir yaşam ne tür bir yaşamdır?”, "nasıl bir yaşam yaşamaya değerdir?", “doğru bir yaşam sürmek için hangi seçimlerin yapılması gereklidir?” türünden birbirini bütünleyen sorular eşliğinde "nasıl yaşamalı?" sorusuna yanıt arayan geleneksel felsefe dalı"36 olarak tanımlayabiliriz. Ahlak felsefesi, insanın dünyadaki var oluş amacını temele alarak insan doğası için iyi olanla kötü olanın neler olduğunu belirginleştirmek için uğraş verir. İnsanın gerek bireysel gerekse sosyal yaşamı içerisinde yüzleştiği sorunları ele alıp, bunların çözümünü kendine vazife edinir. Eleştirel ve ussal bir sorgulama biçimi vesilesiyle doğru bilgi ve ilkelere ulaşmayı ve yeni etik anlayışları elde etmeyi ve bu anlayışları insanlığın hizmetine sunmayı kendine gaye edinen bir düşünce biçimidir. Ayrıca ahlak felsefesini, insanların ahlaksal sorumlulukları ile toplumsal yükümlülüklerinin neler olduğunu

\footnotetext{
34 Arslan, Felsefeye Giriş, 153.

35 Arslan, Felsefeye Giriş, 153-154; Çüçen, Felsefeye Giriş, 275.

36 Ulaş, "Etik", Felsefe Sözlüğ̈̈̈, 500-501; Arslan, Felsefeye Giriş, 118.
} 
ortaya koyan, iyi ve güzel bir yaşam yolunda mutluluğa ulaşmak için nelerin yapılması gerektiği sorusu bağlamında insan eylemlerinin değerlendirilmesine yönelik köklü yaklaşımlar sunan değişik değer öğretileri bütünü ${ }^{37}$ diye de tarif edebiliriz. Özetle ahlak felsefesi, insan davranışları üzerine yapılan etkinliktir.

Filozoflar, felsefeyi genellikle nazari ve ameli olmak üzere ikiye ayırırlar. Birincisi daha çok insanın bilgileriyle, ikincisi ise faaliyetleriyle ilgilidir. Birincisinde başarılı olmak bizi nazari kemale, ikincisinde başarılı olmak ise bizleri ameli kemale götürür. Her ikisi aynı bireyde bir araya gelirse, o kişinin tam ve hakiki saadete ermesi anlamına gelir. Ameli felsefe veya hikmetin üç ana konusu vardır: Ahlak, tedbirü'l-menazil ve siyasetü'l-müdün. ${ }^{38}$ Birincisi ferdin nasıl kemale ereceğini ele alır; ikincisi ahlakı aile çerçevesi içinde düşünür; üçüncüsü ise şehirlerin veya ülkenin ahlaklı ve faziletli yönetimini konu edinir. Bu son bölüm görüldüğü gibi siyaset felsefesi ile hemen hemen aynı hedefe kilitlenmiş gibidir. Ahlakı felsefi açıdan inceleyen ve açılayan bir düşünce biçimi, insan davranışları üzerine yapılan felsefi etkinlik olarak tanımladığımız ahlak felsefesinin terim ve kavramlarının neler olduğunu genel olarak sunarsak, ahlak felsefesinin amacını, konularının neler olduğunu, hangi kavramlar üzerinde çalıştığı hakkında daha sağlıklı bir bilgi edinmiş oluruz. Ahlak felsefesi, olgu ve değer yargıları, iyi ve kötü, özgürlük, erdem, sorumluluk, vicdan, ahlaki karar ve davranış, ahlak yasaları, ahlakın kaynağı, ahlak felsefesi kuramları gibi meseleleri ele almaktadır. ${ }^{39}$

$\mathrm{Bu}$ açıklamalardan sonra gerek siyaset felsefesi gerekse ahlak felsefesinin, "iyi”yi elde etmenin peşinde oldukları söylenebilir. Her ikisi de iyi bir hayat için, iyi bir davranış için ne yapmak gerekir? İyi bir hayat nasıl elde edilir? İyi bir toplum ve iyi bir devlet ne şekilde kurulabilir? İnsana mutluluğu sunmanın en güzel yolu nedir? sorularının cevaplarını aramaktadirlar.

Demek ki siyaseti, yaygın anlamda devleti her alanda idare edecek kuralların bütünü olarak tanımlamak olanaklıdır. Siyaset felsefesi de ahlak felsefesi gibi olması gerekeni ele alır ve gelecekte toplumların nasıl idare edilmesi gerektiğini ortaya koyabilmek için onların dününü ve bugününü inceler. Temelde siyaset felsefesinin cevabını aradığı iki soru olduğu söylenebilir. İlki, insanlardan kimin neye hakkı olacak? Diğeri de herkes adına kim ya da kimler konuşacak?

37 Norman P. Barry, Modern Siyaset Teorisi, çev. Mustafa Erdoğan-Yusuf Şahin, Ankara: Liberte Yayınları, 2012, 348-349; Çüçen, Felsefeye Giriş, 252; Ulaş, “Etik”, Felsefe Sözlü̆̆̈̈, 501.

38 Mehmet, Aydın. "Ahlak" Türkiye Diyanet Vakfı İslam Ansiklopedisi, İstanbul: TDV Yayınları,1989, 2/ 10.

39 Alan Gewırth, "Siyaset Felsefesi”. çev. Ahmet Kesgin, Ankara Üniversitesi İlahiyat Fakültesi Dergisi, 52:1 (2011), 351 
Birinci soruda hak ve özgürlükler söz konusudur. İkinci soru ise siyasi otorite (yani kanun koyma hakkı) ile ilgilidir.40 Temelde bu iki soruya cevap arayan siyaset felsefesinin ele aldığ konular nelerdir? Şimdi bu felsefe dalının hangi konuları ele aldığına kısaca bir göz atalım.

Siyaset felsefesi, devletin kaynağı, amacı, önemi, tarihte yer almış ve günümüzde var olan devletlerin sınıflandırılması ve bu devletlerin oluşumuna etki eden nedenler, ideal düzen arayışları, bireyle-devlet, itaat etmekle özgürlük arasındaki ilişki, baskı, sansür ve yönetimin gücü, adalet, eşitlik, özgürlük, haklar ve mülkiyet gibi temel kavramların analizi ${ }^{41}$ gibi konuları ele almaktadır. Siyaset felsefesinin temelleri Eski Yunan'da atılmış olup, günümüzde siyasi otoritenin gücünü, doğasını ve kaynağını, siyasi otoriteyle birey arasındaki ilişkileri ele alır. Siyaset felsefesi, siyasi kurumların ve bu arada devletle-birey arasındaki ilişkileri nasıl geliştirebileceğini inceler.42 Anlaşılmaktadır ki olanın değil olması gerekenin peşinde olan siyaset felsefesi, hep daha mükemmeli aramakta ve insanlara daha çok hak ve özgürlük, mükemmellik ve daha yüksek bir hayat standardı sunabilecek bir yönetim biçiminin peşindedir.

Siyaset felsefesi, klasik şekliyle Platon ve Aristo tarafından geliştirilmiştir. Daha sonra ise Stoalılar, Ortaçağ İslam ve Yahudi felsefecileri ve Hıristiyan Skolastikler, siyaset felsefesinin bu klasik çerçevesini benimsemişlerdir. İdeal bir toplumun gerçekleşmesi için öğütler veren bu klasik anlayışın filozoflarına göre, rejimin iyisi ile insanın iyisi özdeştir. Erdemli insan ancak erdemli rejimin altında var olabilir, aksi ise mümkün değildir. ${ }^{43}$ Buradan anlıyoruz ki iyi insan ancak iyi bir yönetim biçiminde veya iyi bir rejimde meydana gelebilir. İnsanın kişiliğinin oluşmasında içinde yaşanılan ortamın, çevrenin, aldığı eğitimin, diyalog kurduğu insanların duygu ve düşüncelerinin, ekonomik imkânların ve vatandaşı olunan idare biçiminin etkisi göz önüne alındığında haklılık payının bir hayli yüksek olduğu söylenebilir. Anlaşılmaktadır ki modern siyaset kuramları devlet, iktidar, egemenlik, meşruiyet, hukuk gibi siyasal kavramların analizi ile ilgilenmektedirler. Bu da bize gösteriyor ki modern siyaset kuramları, siyaset

40 Toku, Siyaset Felsefesine Giriş, 19.

41 Gewırth, "Siyaset Felsefesi" çev. Ahmet Kesgin, Ankara Üniversitesi İlahiyat Fakültesi Dergisi, 52: 1 (2011), 349; Cevizci, “Siyaset Felsefesi”, Paradigma Felsefe Sözlüğü, 853.

42 Ulaş, "Siyaset Felsefesi”, Felsefe Sözlüğü, 1308; Cevizci, "Siyaset Felsefesi”, Paradigma Felsefe Sözlü̆̆̈̈, 853.

43 Raynaud Philippe -Stephane Rials, "Siyaset Felsefesi” Siyaset Felsefesi Sözlüğü, çev. İsmail Yerguz, Necmettin Kamil, vd. İstanbul: İletişim Yayınları, 2003, 792; Toku, Siyaset Felsefesine Giriş, 40 
felsefesinin doğru ve haklı bir parçasını teşkil etmektedirler. ${ }^{44}$ Verilen bu bilgi ve yapılan açıklamalardan şu sonuç ortaya çıkmaktadır ki siyaset hayatın kendisidir. Siyaset felsefesi de bu hayat çizgisinde insanoğlunun karşılaştı̆̆1 problemlerin çözümüne pozitif yönde öneriler sunma ve eldeki ile yetinmeyerek daha ideal olanı araştırıp ortaya koymaktır. Siyasetten kaçınmak olsa olsa kötü bir siyaset olur. Çünkü hayatımızın büyük bir bölümü siyasi kurumlar ve süreçler tarafından belirleniyor. Bu yüzden siyasetten kaçmak, hayattan ve hayatımızı belirleyen, yönlendiren temel dinamiklerden kaçmak anlamına gelir ki bu bilinçli bir bireyin seçeceği yol olamaz.

Siyaset felsefesinin problemleri insanların toplum halinde ve siyasal bir örgütlenme içinde yaşamalarından doğan siyasi problemlerdir. Bu problemlerin en önemlileri doğal olarak egemen varlığa, yani devlete ilişkin problemlerdir. Siyaset felsefesi egemen varlığı konu alan devlet felsefesinin kendisinden başka bir şey değildir. ${ }^{45}$ Siyaset felsefesinin problemlerini, devletin kendisinin gerekli olup olmadığını soruşturma, devleti kimin yönetmesi gerektiği, bireyle devlet arası ilişkilerin ne şekilde olması gerektiği, ideal düzeni belirleyen ölçütler, karmaşa, düzen, ütopya diye belirleyebiliriz. ${ }^{46}$

\section{Siyaset Felsefesinin Bazı Kavramları}

Siyaset-ahlak felsefesi ilişkisine de kısaca temas ettikten sonra siyaset felsefesinin bazı kavramlarını ele alıp konunun sınırları çerçevesinde açıklamaya çalışacağız. Takdir edilmelidir ki bir şey hakkında sağlıklı, tutarlı bir değerlendirme yapabilmek, rasyonel çıkarımlarda bulunabilmek için onu bize tanıtacak temel kavramları açık seçik bilmek gerekir. Aksi halde pozitif sonuç elde etmemiz güçleşecektir. Felsefenin problem alanlarından biri olan değer sahasının alt disiplini olan siyaset felsefesini anlamak için, öncelikle yapılması gereken şey, kavramlarını açık ve seçik olarak tanımlamaktır. Siyaset felsefesinin temel kavramları şunlardır: Birey, toplum, sivil toplum, devlet, iktidar, yönetim, meşruiyet, egemenlik, hak, hukuk, yasa ve bürokrasidir.

Birey (Fert): Ferd (çoğulu efrad ) sözlükte "tek, yegâne, eşi olmayan" anlamına gelir. Siyaset felsefesinde tek insan varlığı anlamına gelen birey, kendisini diğer insanlardan ayıran, kendisine ait bir varlığı olan kişidir. Birey, diğer bireylerle birlikte toplumda yaşayan ama bazı

\footnotetext{
44 Arslan, Felsefeye Giriş, 155.

45 Arslan, Felsefeye Giriş, 157.

46 Çüçen, Felsefeye Giriş, 325; Arslan, Felsefeye Giriş, 158-162.
} 
özellikleriyle topluma bağımlı bazı özellikleriyle göreli özgür bir varlıktır. Tabi ki birey, birey olarak kendisini gerçekleştirmek için, topluma ve devlete ihtiyaç duyar. ${ }^{47}$ Buradan da anlaşıldığı gibi bireyin kendini tam olarak tanımlaması ve ifade edebilmesi için bir topluma ve bir devlete ihtiyacı vardır. Toplum ve devlet olmadan bireyden ve bireyin haklarından, onun insani ve toplumsal ilişkilerinden bahsedemeyiz.

Toplum: Toplum, tek tek tüm ihtiyaçlarını gideremeyen insanların fiziki ve sosyal ihtiyaçlarını gidermek için bir araya gelip, belli bir bölgede oluşturdukları düzenli insan grubudur. Bireylerin çeşitli amaçlar doğrultusunda ortak bir kültür çevresinde toplanmasıla toplum oluşur. Aynı toprak parçası üzerinde bir arada yaşayan ve temel çıkarlarını sağlamak için iş birliği yapan insanların tümüne, cemiyet ${ }^{48}$ diyebiliriz. $O$ halde, bireysiz toplum olamayacağı gibi, toplum olmadan da bireylerin kamil manada ihtiyaçlarını temin etmesi ve varlığını devam ettirmesi kolay olmayacaktır.

Sivil Toplum: Toplumun, devletin kurumlarının dışında, kendi kendisini yönetmek ve yönlendirmek amacıyla kurduğu demokratik yapıya sivil toplum denir. Sivil toplum ve kurumları, özgür vatandaşların bir araya gelmesi sonucu istek, arzu ve haklarını devlete karşı savunacakları birimlerdir. Sivil toplum, ancak hukuk devletinin olduğu bir rejimde gerçekleşebilir. Sivil toplum kavramının kapsamına kabileler, feodal beylikler, uluslar, krallıklar, imparatorluklar, siteler... girmektedir. Her sivil toplum kendine özgü karmaşık ve değişken yapılar, kültürel modeller, fikirler ve değerlerle kısaca ortak bir örgütlenme ve zihniyetle belirlenir. Sivil toplumu, sosyal hayattaki çeşitli sorunları bağımsız olarak ele alıp kamuoyunu bilgilendirme ve aydınlatma görevi yapan, öneriler sunan her türlü birlik ${ }^{49}$ diye de tanımlayabiliriz. Görüldüğ̈̈ üzere sivil toplum kuruluşlarının amacı hukuk kuralları çerçevesinde toplumdaki problemleri ele alıp, kamuoyunu bilgilendirme ve aydınlatma ve bunların çözümü konusunda öneriler sunmak, insanların hak ve isteklerini devlete karşı savunmaktır.

47 İbn Manzur, Muhammed b. Mükerrem, Lisanü'l-Arab, "frd”, Der Sadır, Beyrut Lübnan, 15/1990; Selahaddin, Polat. "Ferd", Türkiye Diyanet Vakfi İslam Ansiklopedisi, İstanbul: TDV Yayınları,1995, 12/ 368-369; Çüçen, Felsefeye Giriş, 340; Ulaş, "Bireycilik” Felsefe Sözlüğü, 243; Şükrü Haluk Akalın vd., "Birey", Türkçe Sözlük, Ankara: Türk Dil Kurumu, 10. Basım, 2005, 280; Bolay, "Birey", Felsefi Doktrinler ve Terimler Sözlü̆̆̈̈, 48.

48 Akalın, "Toplum", Türkçe Sözlük, 1993; Çüçen, Felsefeye Giriş, 317; Ulaş, "Toplum Felsefesi", Felsefe Sözlüğü, 1431.

49 Çüçen, Felsefeye Giriş, 317; Akalın, "Sivil Toplum Kuruluşu", Türkçe Sözlük, 1778; Çam, Siyaset Bilimine Giriş, 74; Bolay, "Sivil Toplum”, Felsefi Doktrinler ve Terimler Sözlü̆̆̈̈, 365. 
İktidar: Bir işi yapabilme gücü, erk, kudret demektir. İktidarı, devlet yönetimini elinde bulundurma ve devlet gücünü kullanma yetkisi ${ }^{50}$ diye de tanımlayabiliriz. Genel anlamiyla, kendi istencini egemen kılabilme gücü olan iktidar, siyasal olarak ise bir toplumun egemenliğini elinde bulunduran gücü ifade etmektedir. ${ }^{51}$ İktidarda olan güç, hukuk kuralları çerçevesinde devletin gücünü elinde bulundurur ve bu güce göre bir yönetim sürdürür. İktidar, insanların ya da bireylerin eylemde bulunma, yapıp etme yetisi, belli bir işi başarma, ortaya bir takım etkiler ya da sonuçlar çıkarabilme yeteneğidir diyebiliriz. İktidar kavramı içinde, fiziksel ya da tinsel bir etki yaratabilme ya da bu tür bir etkiye karşı direnebilme yeteneğini de barındıran bir terimdir. Toplumda doğrudan ya da dolaylı yollarla değişimi meydana getirme ya da olası değişimleri önleyip önüne geçme kapasitesi de iktidar kavramının anlamlarındandır. İktidar gücü, devletlere, hükümetlere ya da kurumlara ellerinde bulunan iş ve işlemleri yapma yetkisi veren kaynaktır. ${ }^{52} \mathrm{Bu}$ tanımdan da anlaşılacağ 1 üzere iktidar kavramının etki alanı bir hayli geniştir. Fiziksel, siyasi, psikolojik, toplumsal, hukuksal pek çok sonucunun olduğunu rahatlıkla ifade edebiliriz. Anlaşılmaktadır ki iktidar kavramı, siyaset, toplum ve devlet mekanizmalarında hayati bir değere sahiptir.

İktidar kavramı otoriteyi de içerir. Otoritenin görüldüğü her yerde yöneten ve yönetilen ayrımı bulunur. İnsanlar arasındaki etkileşim sonucu eşitsizlikte ortaya çıkar. İktidar toplum içerisindeki toplumsal ilişkilerin eşitsizlik biçiminde oluşmasıdır. Toplumsal ilişkiler, mutlak bir karşılık ve eşitlik düzeyinde gelişseydi, toplumsal denge kendiliğinden oluşurdu ve iktidar kendiliğinden gereksizleşirdi. ${ }^{53}$ Demek ki iktidarı ortaya çıkaran ve iktidara gereksinim alanı açan temel faktörlerin başında toplumdaki ve toplumsal ilişkilerdeki eşitsizlik ve dengesizlik gelmektedir. Otoriteye toplumun en küçük birimlerinde bile, hatta ikili ilişkilerde dahi rastlayabiliriz. Otoritenin olduğu her yerde yöneten ve yönetilen ayrımı bulunur. ${ }^{54}$ Herhangi bir kişinin iktidar sahibi olabilmesi için toplum içinde var olan bazı araçları elinde tutması gerekir. $\mathrm{Bu}$ araçlar mal, maddi servet olabileceği gibi bilgi, yetenek gibi soyut kavramlar da olabilir. İktidar kavramı, karar alma ve onu uygulama, uygulatma gücünü içerir. Siyasi iktidar, tüm

50 Heywood, Siyasetin Temel Kavramları, 44; İsmail Durmuş, "İktidar", Türkiye Diyanet Vakfı İslam Ansiklopedisi, İstanbul: TDV Yayınları, 2000, 22/56; Akalın, "İktidar", Türkçe Sözlük, 951; Öztekin, Siyaset Bilimine Giriş,10; Bolay, “İktidar”, Felsefi Doktrinler ve Terimler Sözlü̆̆̈̈, 187.

51 Çüçen, Felsefeye Giriş, 317.

52 Ulaş, "Güç/İktidar" Felsefe Sözlü̆̆̈̈̈, 628; Çam, Siyaset Bilimine Giriş, 61.

53 Kışlalı, Siyaset Bilimi, 4; Çam, Siyaset Bilimine Giriş, 61.

54 Çam, Siyaset Bilimine Giriş, 61; Kışlalı, Siyaset Bilimi, 4. 
toplumu etkileyen ve kapsamına alan etkileme ve yaptırım gücüdür. ${ }^{55}$ Burada iktidar kavramı ile ilgili bu kadar bilgi ile yetinip, siyaset felsefesinin diğer bir kavramı olan yönetim ilkesine geçiyoruz.

Yönetim: Yönetme işi, çekip çevirme, idare ${ }^{56}$ anlamına gelmektedir. Yönetim bir kurumu, toplumu ve devleti belli kurallar, ilkeler ve amaçlar çerçevesinde çalıştırma, yönetme ve yönlendirme anlamını içermektedir.57 Yönetme kavramı siyaset felsefesinin en temel kavramlarından biri olup, bir kurumun, devletin, toplumun siyaseten ve ahlaken yetkin bir yönetim anlayışı tarafından idare edilmesi önem arz etmektedir. Çünkü ehil ve yetkin yönetim anlayışının iş başında olduğu kurumda, toplumda ve devlette her alanda verim ve mutluluğun üst düzeyde olması kaçınılmazdır. Aksi takdirde o toplum, kurum ve devlette siyaset felsefesinin temel hedefi olan bireyleri mutlu etme idealinin gerçekleşmesi hedefi zayıflamıştır.

Meşruiyet: Meşruiyet kavramının çağrıştırdığı ilk anlam yerleşik kurallara ve prosedüre uygunluktur. Genel olarak yasallık anlamına gelir. Sözcük anlamı, yasallık veya yasaya uygunluk olan meşruiyet, yapılan eylemin veya etkinliğin yazılı yasaya, pozitif hukuka uygun olması demektir. Bir eylemin meşru olması, dayandı̆̆ı ahlak ilkesine bağlı olmaktan çok, yasaya, yani pozitif hukuka uygunluğuna bağlıdır.58 Sözlükte "açılamak, açığa çıkarmak, bir işe başlamak, uyulmaya değer adet başlatmak, din-hukuk kuralı koymak" gibi manaları içeren şer kökünden gelen meşru, İslami literatürde dini kaynaklara dayalı hükümleri veya dine ve ilkelerine uygun olan eylem ve işlemleri ifade eden bir terimdir. ${ }^{59}$ Meşruiyet kavramının farklı anlayışlarda ortak bir anlayışla "yasaya uygun, haklı, doğru” gibi manalar içerdiğini söyleyebiliriz. Gerek Batı gerekse İslam kültüründeki yaygın anlamıyla meşru “dinin, yasanın veya kamu vicdanının doğru bulduğu şey" demektir. ${ }^{60}$ Eğer mevcut ahlak ve hukuki norma uygunluk arz etmiyorsa o kurum ya da kuralın meşruluğundan söz edilemez. Meşruiyet, benimsenen değerler sistemine yani din, ahlak, hukuk, gelenek ve görenek gibi farklı kaynak ve yaptırıma sahip sosyal düzen kurallarına uygunluğu ifade eder. Bir değerin toplumca ne düzeyde benimsendiği sosyolojik bir sorun olmakla beraber itibarını yitirmiş bir anlayış

55 Öztekin, Siyaset Bilimine Giriş,10; Kışlalı, Siyaset Bilimi, 4.

56 Akalın, "Yönetim", Türkçe Sözlük, 2196.

57 Çüçen, Felsefeye Giriş, 318.

58 Çüçen, Felsefeye Giriş, 318; Türkçe Sözlük, "Meşruiyet", 1380; Bolay, "Meşruiyet", Felsefi Doktrinler ve Terimler Sözlüğü, 277.

59 Bilal Aybakan - İbrahim Kâfi Dönmez, "Meşru”, Türkiye Diyanet Vakfı İslam Ansiklopedisi, Ankara: TDV Yayınlar1, 2004, 29/378-379.

60 Aybakan-Dönmez, "Meşru”, Türkiye Diyanet Vakfı İslam Ansiklopedisi, 378. 
toplumun tepkisini çekmeye adaydır. Bununla birlikte normatif doğruluğun ölçüsünün toplum mu yoksa akıl mı olduğu hususu tartışmalı bir konudur. Elbette ki kamu vicdanını rahatsız eden bir karar veya durum kanuni de olsa meşru sayılmaz. Toplumun adalet anlayışının aynası olan maşeri vicdan bir anlamda meşruiyeti belirleyen en önemli unsurdur. Demek oluyor ki bir kanun veya işlem maşeri vicdanın sesini temsil ederse meşruiyet temeli kazanır. Bununla birlikte pek çok alana göre pek çok meşruiyet türünden bahsedebiliriz. Bunları siyasi meşruiyet, Hukukta meşruiyet, Milletlerarası meşruiyet, Sosyolojik meşruiyet gibi bölümlere ayırabiliriz. Biz çalışmamızın hedefi ve konusu gereği siyasi meşruiyeti kısaca ele almak ve değerlendirmek istiyoruz.

Siyasi meşruiyet, iktidara gelişte ve iktidarı kullanışta yerleşik ilkelere, yani toplumun genel kabulüne mazhar olmuş usullere ve siyasi - ahlaki değerlere uygunluk ${ }^{61}$ olarak tanımlanır. Siyaset felsefecileri meşruiyeti, yönetimlerin genellikle vatandaşlardan itaat etmelerini talep etmelerini sağlayan bir zemin olarak ahlaki veya rasyonel bir ilke olarak ele alırlar. ${ }^{62}$ Siyaset bilimcileri ise meşruiyeti, nasıl sağlanırsa sağlansın bir kurallar sistemine boyun eğme isteği olarak görürler. Buradan anlıyoruz ki siyaset biliminde meşruiyet, yönetilenlerin değil yönetenlerin tasarruflarını, bir başka anlatımla eşitler arasında değil güçlü ile zayıf arasındaki ilişkilerde güçlü olanın zayıfa yönelik davranışlarında dikkate alması gereken mülahazaları ilgilendiren bir kavram olup, siyasi iktidarın kurumsallaşması yanında ahlaki açıdan temellendirilmesine imkân veren süreci ifade eder. Siyasi meşruiyet, tanınmış ilkelere dayalı yönetme hakkı olduğuna göre yönetim emirlerini uygulatmak için ihtiyaç duyduğunda zor kullanma yetkisine de sahiptir.

Egemenlik: Siyaset felsefesinin temel kavramlarından biri de egemenliktir. Egemenlik devletin, belli sınırlar içerisinde, belli bir toplumda, serbestçe iktidar gücünü kullanabilmesidir. Yani dış ve iç baskılardan kurtularak devleti yönetebilmesidir. Devletlerarası ilişkiler açısından hukuken, bir devletin diğer devletlere ve federal otorite veya milletler cemiyeti gibi diğer otoritelere karşı mutlak bağımsız olmasıdır. ${ }^{63}$ Devleti devlet yapan temel güçlerin başında insan topluluğu, sınırları belirlenmiş bir toprak ve egemenlik kavramı gelmektedir. Egemenlik gücü,

\footnotetext{
61 Aybakan-Dönmez, "Meşru", Türkiye Diyanet Vakfi İslam Ansiklopedisi, 379.

62 Heywood, Siyasetin Temel Kavramları, 49.

63 Bolay, "Egemenlik", Felsefi Doktrinler ve Terimler Sözlüğ̈̈, 119; Heywood, Siyasetin Temel Kavramları, 35; Akalın, "Egemenlik", Türkçe Sözlük, 604.
} 
devletin iktidar gücünü hiçbir iç veya dış baskı olmadan kullanma gücüdür. ${ }^{64}$ Anlaşılmaktadır ki egemenlik, devleti devlet yapan temel güçtür. Bu yüzden devletin içinde veya dışında ondan daha büyük bir güç olmamalıdır. Egemenlik bir devletin diğer devletlere karşı bağımsız olduğunun en önemli simgesidir. Buda şu anlama gelmektedir ki egemenliğin en önemli göstergesi devletin özgür olarak kendi kendini yönetmesidir. Yine egemenlik, iktidarın devlette iş yapabilme, örneğin emredebilme, para basabilme, ordu kurabilme, denetim yapabilme gibi özelliklerini belirtir.65 Egemen devlet iç ve dış politikaya ilişkin alacağı kararlarda öteki devletlerin ve çok uluslu güçlerin etkisinde kalmadan, kendi ulusal çıkarları için kararlar alabilen devlettir.

Bağımsız bir devletin vazgeçilmez niteliklerinden olan egemenliğin başlıca iki anlamda kullanıldığını görmekteyiz. Bunlardan birincisi, egemenliğin ilk ve orijinal anlamıdır. Bu, yukarıda da ifade ettiğimiz gibi devletin iktidarının en üstün olma, sınırsız ve mutlak olma, bölünmez ve devredilmez olma gibi niteliklerini belirten tanımıdır. Diğer anlamıyla ise egemenlik, devlet iktidarının niteliğini değil, fakat doğrudan doğruya kendisini, onun içeriğini ve kapsamını ifade eden bir terim olarak karşımıza çıııyor. Bu tanımlamada egemenlik devletin "kanun yapmak, savaş ve barış ilan etmek, para basmak, vergi toplamak gibi icraatlarını kapsamaktadır.66 Buradan şu sonuca varabiliriz ki egemenlik anlayışı geçmişte olduğu gibi günümüz siyaset bilim ve hukuk devlet anlayışında da önemini korumaktadır ve egemenlik bir devlet ve toplumun bağımsızlı̆̆ının simgelerindendir.

Hak: İlk anlamıyla hak, hukuk devletinin yapılmasına izin verdiği ve yasa, tüzük, yönetmeliklerde belirlediği serbestliktir. Hak, adaletin, hukukun gerektirdiği veya birine ayırdığı şey, kazançtır. Sözlükte "gerçek, sabit ve doğru olmak, gerekmek, bir şeyi gerçekleştirmek, bir şeye yakinen muttali olmak"67 anlamlarında isim olan hak kelimesi genellikle batılın zıddı olarak kullanılır. Bizim başkalarına karşı yapmamız gereken, başaklarının da bize karşı yapması gereken şey hak'tır. Bu bakımdan hak, aynı zamanda bir şeyi ahlaki olarak yapma gücüdür. Hak ahlaki anlamda ödevle ilgilidir. Bu anlamda insanın her

64 Çüçen, "Egemenlik", 318; Öztekin, Siyaset Bilimine Giriş, 17.

65 Çüçen, Felsefeye Giriş, 318.

66 Kapani, Politika Bilimine Giriş, 59-61.

67 İbn Manzur, Lisanü'l-Arab, "hkk"; Mustafa Çă̆rıcı, "Hak”, Türkiye Diyanet Vakfı İslam Ansiklopedisi, İstanbul: TDV Yayınları, 1997, 15/137; Çüçen, Felsefeye Giriş, 318; Bolay, "Hak", Felsefi Doktrinler ve Terimler Sözlü̈̆̈̈, 169; Akalın, “Hak”, Türkçe Sözlük, 829. 
hakkı, başkalarına karşı bir vazifeyi yapmayı gerektirir. Toplum içinde yaşamak hakkımızdır, ama toplumun fertlerine iyi davranmak görevimizdir. ${ }^{68}$

Siyasi manada hak, bir kanun veya kural ile verilmiş olan fiildir. Burada da kurala uygunluk vardır. İnanç ve düşüncelerini ifade hakkı, siyasi ve sosyal haklar bunlardandır. Biz hakları, kamu ve özel hukuktan doğan haklar olmak üzere ikiye ayırabiliriz. Kişinin toplum ve devletle ilişkisini düzenleyen yasaların verdiği izinler kamu haklarını, kişinin özel yaşamında izin verdiği haklar ise özel olanı kapsar. ${ }^{69}$ Altın ve gümüş alma gibi haklar özel haklar iken, bireyin seçme ve seçilme hakkı kamu hakkıdır. Anlaşılmaktadır ki her iki anlamda da hak, ödev bilinci ve sorumluluğunu gerektirir. Haklar sorumluluk alındığında anlamlıdır. Ödünç para aldığımızda, aldığımız parayı sıkıntımızı giderdikten sonra zamanın da geri iade etmemiz bir sorumluluktur, yani bir ödevdir. Toplumu oluşturan bireyler iyi bilmeliler ki her hak bir sorumluluk gerektirir. Sorumluluğunu yerine getirmeden hakkını kullanmaya kalkmak medeni ve duyarlı bir ferdin davranışı olamaz, olmamalıdır. Hatta sorumluluğunu yerine getirmeyen bir kişinin hakkını kullanmaya hakkı olmamalıdır da denilebilir. Hakkım var sözü, sorumluluğum var sözüyle eşdeğer tutulmalı ve böyle uygulanmalıdır. Böyle algılayan ve uygulayan toplumlarda sağlıklı bir hak anlayışı vücut bulur. Buna bağlı olarak da siyaset felsefesinin temel gayelerinden biri olan mutlu ve adil bir yönetim ve toplum şekli oluşur.

Hukuk: Bir başka siyaset felsefesi terimi de "hukuk" tur. İnsan sosyal bir varlık olup, bir toplum içerisinde yaşadığına göre, toplum ve birey ilişkilerini düzenleyen, belirleyen ve devletin yaptırım gücüyle uyulması zorunlu kılınan davranış kurallarının oluşturduğu sisteme hukuk denir..$^{70}$ Hukuk kuralları yaptırıma sahiptir. Bu yüzden, hukuka aykırı davranmak veya kanunu çiğnemek, mutlaka bir ceza ile neticelenir. Hukuk kurallarına uyulması için bazı yaptırımlar uygulanır. Para cezası, hapis cezası bunlardandır. Burada şu sorular akla gelebilir: Hukuk nereden doğmuştur? Hukuku doğuran etkenler nelerdir? Yukarıda da ifade ettiğimiz gibi, insan tabiatı icabı bir arada yaşamak durumunda olan yani toplumsal bir varlıktır. Dolayısıyla hukuk, ihtiyaçların giderilmesi ve güvenliğin sağlanması zaruretinden doğmuştur

68 Andrew Heywood, Siyaset Teorisine Giriş, çev. Hızır Murat Köse, İstanbul: Küre Yayınları, 2011, 313; Bolay, "Hak", Felsefi Doktrinler ve Terimler Sözlü̈̆̈̈̈, 169.

69 Heywood, Siyasetin Temel Kavramları, 178; Çüçen, Felsefeye Giriş, 318-319; Bolay, "Hak", Felsefi Doktrinler ve Terimler Sözlü̆g̈̈, 169.

70 Heywood, Siyasetin Temel Kavramları, 38; Akalın, "Hukuk", Türkçe Sözlük, 903; Bolay, "Hukuk”, Felsefi Doktrinler ve Terimler Sözlüğ̈̈, 179-180; Çüçen, Felsefeye Giriş, 319. 
diyebiliriz. Bu ihtiyaç ve zaruretler toplumda bir takım kuralların bulunmasını zorunlu kılmıştır ki hukuk bu kuralların konulması, düzenlenmesi ve uygulanmasıdır.

Sonuç olarak hukukun varlığı, toplum içinde olması kuvvetle muhtemel kaos, kargaşa, adaletsizlik gibi olumsuz davranış türlerinin olmaması veya en azından asgariye indirilip huzurun sağlanması ve devamının temini için zorunludur.

Yasa: Devletin yasama organları tarafından konulan ve uyulması gereken kurallar bütünü, kanundur. Toplumsal hayat içinde kendiliğinden oluşan ve uyulması toplum içinde yaşamanın bir mecburiyeti olan alışkanlıkların bütünüdür. Devletin, bireylerin ilişkilerini düzenlemek ve kargaşaya mahal vermemek için koyduğu kurallardır. Toplumun bireylerine, içinde yaşadıkları cemiyetin kurallarına uymaları gerektiğini bildiren yazılı buyruklardır. ${ }^{71}$ Burada görmekteyiz ki bir toplumun içinde kendiliğinden oluşan ve yazılı olmayan bir de devletin koyduğu ve yazılı olan yasalar vardır. Her ikisine de uyulmadığında problemin çıktığı ortadadır. Devletin koyduğu yasaların resmi bir yaptırım gücü söz konusu iken, toplum içinde kendiliğinden oluşan yasaların ihlalinde ise kamu vicdanı tarafından bir kınanma ve tepki görme söz konusudur. Sonuçta her ikisi de toplumun birliği ve beraberliği, huzuru ve mutluluğu için mevcuttur. Her iki yasa türüne de ihtimam gösterip, önemseyip ve içselleştirerek benimsediğimizde sağlıklı bir toplum olma yolunda mesafe kat etmiş olacağız.

Bürokrasi: İnsanoğlunun ihtiyaç duyduğu kamu hizmetlerinin düzenli, yasalı ve eşit yapılabilmesi için bir teşkilatın varlığı zorunludur. Işste bu hizmetlerin eşit ve düzenli yapılabilmesi amacıyla kurulmuş hiyerarşik örgüte verilen isim bürokrasidir. Devlet, oluşturduğu yasa, tüzük ve yönetmelikleri bürokrasi aracılığı ile düzenli olarak yürütmektedir. Bürokrasi aşağıdan yukarıya daralan bir yapıyla ve kişisel ilişkilere dayanmadan genel kurallar çerçevesinde devletin işlerini yürüten organdır. Bürokrasinin merkezi fonksiyonu hukuk ve politikayı uygulamak ve yerine getirmektir. Devletin işlemesi ve devamlılığın sağlanabilmesi için siyasi iktidar değişikliklerinden etkilenmeyen sürekli bir yönetim cihazına ihtiyaç vardır. İşte bürokrasi, bu sürekli idare cihazının adıdır. ${ }^{72}$ Bürokraside çalışan memurların yapacakları işlerin tarifi yapılmış, iş bölümü esasına göre iş tasnifi belirlenmiş ve bu anlayışa uygun bir hiyerarşi söz konusudur. Bürokrasinin görevi işleri kolaylaştırmaktır. Fakat zaman zaman

71 Fethi Gedikli, "Yasa”, Türkiye Diyanet Vakfı İslam Ansiklopedisi, İstanbul: TDV Yayınları, 2013, 43/336; Bolay, "Yasa", Felsefi Doktrinler ve Terimler Sözlüğü, 447; Çüçen, Felsefeye Giriş, 319; Akalın, "Yasa", Türkçe Sözlük, 2140; Heywood, Siyasetin Temel Kavramları,38-39.

72 Heywood, Siyasetin Temel Kavramlarl, 271; Çüçen, Felsefeye Giriş, 319; Bolay, "Bürokrasi", Felsefi Doktrinler ve Terimler Sözlüğ̈̈, 56; Akalın, "Bürokrasi”, Türkçe Sözlük, 335. 
bunun tam tersi durumlarda söz konusu olmaktadır ki bürokrasi bazen işlerin daha da uzamasına ve zor halledilir olmasına da sebep olabilmektedir. Buda, bürokrasinin kuruluş amacının dışına çıkması anlamına gelmektedir. Bu durumda problem çözme makamı, problemlerin çözümünü zorlaştırma ve hatta bazen kendisi problem haline gelebilmektedir. Bu anlayış ise o ülke ve ülke insanı için hayatı zorlaştırıcı olmaktadır.

Adalet: Siyaset felsefesinin temel kavramlarından biride adalettir. Adalet, ferdi ve içtimai yapıda dirlik ve düzenliği, hakkaniyet ve eşitlik ilkelerine uygun yaşamayı sağlayan ahlaki erdemdir.73 Adalet, "davranış ve hükümde doğru olmak, hakka göre hüküm vermek, eşit olmak, eşit kılmak" gibi manaları içermesinin yanında her bir kişiye, genellikle adilane hak edişleri olduğu düşünülen şeyi, yani kendi hakkını vermek anlamına da gelen bir kavramdır. Siyasal sistemlerin, bireyler arasındaki ilişkilerin ve eylemlerin ahlak bakımından adil ya da doğru olma niteliği, adil davranma ilkesidir. Eylemde adil olma niteliğini ya da ilkesini gösterme, dürüstlüktür. Bir eylemin ahlaki doğruya, ahlaksal usa ya da gerçeğe uygun olmasıdır. Hakkın ya da haktanırlığın hüküm sürmesidir. İlkçağ Yunan felsefesinden bu yana dört temel erdemden biridir. ${ }^{74}$ Kimi yerlerde "toplumsal adalet" diye de adlandirılan bölüştürücü adalet, herkesin hak ettiğini ya da payına düşeni alması için kaynakların ve görevlerin adil paylaşımını tanımlayan ilkeleri belirler. ${ }^{75}$

Bakıldığında modern dönemde ahlak felsefesi en genel anlamda bir ikilik üzerine kuruludur. Bu ikiliğin bir tarafında siyaset felsefesinin olduğu gibi hukukun, ahlakın da temel bir kavramı olan adalet bulunmaktadır. Diğer tarafta ise insanlık ve onda içerimlenen yardımseverlik, iyilik, cömertlik, konukseverlik ve benzeri erdemler bulunmaktadır. Bu yüzden Platon, sosyal ahlakın bu temel ilkesini, herkesin kendine düşen görevi gerçekleştirmesi olarak tanımlamaktadır. Onun asıl önemi ise öteki erdemlerin devlet çerçevesinde gerçekleşip

73 Heywood, Siyasetin Temel Kavramları, 163; Çağrıcı, "Adalet", Türkiye Diyanet Vakfı İslam Ansiklopedisi, $1 / 341$.

74 Aristoteles, Politika. çev. Furkan Akderin, İstanbul: Say Yayınları, 2013, 1280a,101; Larry Arnhart, Siyasi Düşünce Tarihi, çev. Ahmet Kemal Bayram, Ankara: Adres Yayınları, 2004, 73; Veli Urhan. Siyaset Felsefesinde Adalet, Eşitlik, Özgürlük. Kaygı Uludağ Üniversitesi Fen-Edebiyat Fakültesi Felsefe Dergisi, 26/Bahar (2016), 104; Ulaş, "Adalet", Felsefe Sözlü̆g̈̈, 10; Çağrıc1, "Adalet", Türkiye Diyanet Vakfı İslam Ansiklopedisi, 1/341; Heywood, Siyasetin Temel Kavramları, 163; Akalın, "Adalet", Türkçe Sözlük, 18; Bedia Akarsu, "Adalet" Felsefe Terimleri Sözlüğü, İstanbul: İnkılap Kitabevi, 1994, 17; Ahmet Cevizci, "Adalet", Paradigma Felsefe Sözlüğü, Ankara: Ekin Yayınları, 1996, 11.

75 Heywood, Siyasetin Temel Kavramları ,163; Ulaş, "Adalet", 10; Türkçe Sözlük, "Adalet", 18 
yaşamasına olanak sağlamasıdır. Aristoteles'e göre ise adalet topluluk hayatının temelidir ve haksızlık yapmak ile haksızlığa katlanmanın arasında bulunan doğru ortadır. ${ }^{76}$

İslam felsefesinde adalet, öncelikle ontolojik bir kavram olarak ele alınmış ve bu kavram feyz ve sudur sırasında her varlığın, kendi mertebesine göre "Ilk Varlık" tan bir varlık payı alması şeklinde açıklanmıştır. Buna göre Allah'ın adaleti, var olan her şeye varlık hiyerarşisi içindeki durumuna göre tamlık ve mükemmellik kazandırmasıdır. Böylece İslam Filozofları ilahi inayete bağlı olarak adaletin, varlık sahnesinde yer alan her varlığın bütün gelişim safhalarında ve hatta her cüzünde tecelli ettiğini söylemişlerdir. Nitekim Farabi insanın biopsişik yapısının işleyişinde de adaletin bulunduğunu belirtmiştir. Buna göre kalbin hizmetinde bulunan beyin, onun ısısını dengede tutar ve bu sayede öğrenme ve hatırlama, tahayyül ve düşünme gibi psikolojik aktivitelerin sağlıklı bir şekilde işlemesi demek olan adalet gerçekleşir. Bunun sonucunda da insana yakışır fiiller, iyi ve dengeli davranışlar doğar. ${ }^{77}$ Görüldüğü gibi toplumsal hayatın her tabakasında olduğu gibi devletlerin, sistemlerin, tabiattaki düzenin ve hatta insan vücudun organlarının işlemesinde ve çalışmasında da bir uygunluk, bir düzen ve adalet söz konusudur. Daha öncede ifade ettiğimiz gibi adalet toplumsal hayatın, hukuk sistemlerinin ve siyaset felsefesinin temel bir değeridir. Aynı şekilde toplumdaki huzurun, refahın, mutluluğun, birlik beraberliğin, kardeşliğin teminatı olduğu gibi kaosun, düzensizliğin, nizamsızlığın da vuku bulmasına, ortam bulmasına en büyük ve en temel engeldir.

Eşitlik: Siyaset felsefesinin temel kavramlarından biri olan eşitlik, insanların temel haklar bakımından ve insan olma niteliği itibariyle aynı kabul edilmesini ifade eden ahlak ve hukuk kavramıdır. İnsan hakları, tür olarak insanın en temel iki var oluşsal ahlaki değerinden kaynaklanan haklardır. Bu iki var oluşsal ahlaki değerlerden birincisi özgürlük, diğeri ise bütün insanların insan olmak bakımından aynı değere sahip olmak anlamında eşitliktir. Eşitlik, iki veya daha çok şeyin eşit olması durumu, denklik, müsavat, muadelet anlamlarına gelmektedir. Kanunlar yönünden insanlar arasında ayrım bulunmaması durumu, bedensel, ruhsal, başkalıkları ne olursa olsun, insanlar arasında toplumsal ve siyasi haklar yönünden ayrım bulunmaması durumu ${ }^{78}$ diye de tanımlayabiliriz.

76 Frank Thilly. Felsefe Tarihi. çev: İbrahim Şener, İstanbul: 1995, 136; Macit Gökberk. Felsefe Tarihi. İstanbul: Remzi Kitabevi, 1996, 67-88-89.

77 Çağrıcı, "Adalet", Türkiye Diyanet Vakfi İslam Ansiklopedisi, 1/342.

78 Louis Gardet, Müslüman Site, Toplumsal ve Siyasi Hayat, çev. Ahmet Arslan, İstanbul: Ayrıntı Yayınları, 2014, 56; Arnhart, Siyasi Düşünce Tarihi, 73; Nevzat Can, Siyaset Felsefesi Problemleri, Ankara: Elis 
Eşitlik çoğu zaman amaçlanmaya değer bir politik hedef veya ideal olarak sunulur. Eşitliğin farklı farklı taraflarını savunan pek çok düşünür söz konusudur. Eşitliği nasıl anlamalıyız? Açıktır ki insanlar her bakımdan eşit olamazlar. Bireyler zekâ, güzellik, atletik beceri, boy, saç rengi, doğum yeri, giyim tarzı ve daha birçok bakımdan birbirlerinden farklılık gösterirler. İnsanların birbirlerine her bakımdan mutlak olarak eşit olduğunu öne sürmek pek sağlıklı bir yaklaşım değildir. ${ }^{79}$ Biz çalışmamızın içeriği gereği daha çok siyasal ve toplumsal haklar yönünden bir eşitliğin varlığından ve var olması gerektiğinden bahsedebiliriz. Kanunların düzenlenişi ve uygulanışı, siyasi ve sosyal birtakım haklardan ve bu hakların verdiği imkânlardan yararlanma noktasında mutlak bir eşitliğin var olması gerektiği talep edilmeli ve bu sağlanmalıdır. Takdir edilecektir ki bu ilkenin mükemmellik içinde uygulanması, o toplumun huzur ve mutluluğunun da en büyük göstergesi olacaktır. Eşitlik ilkesinin bihakkın yerine getirilmediği toplumlarda toplumsal anlaşmazlıklar, yönetenle yönetilen kitleler arasında bir güvensizlik vuku bulacak, bu durumda doğal olarak bir güven problemi doğuracaktır. Güven duygusunun olmadığı bir toplum, bir ülkede ise siyaset felsefesinin temel hedefi olan mutluluktan söz edilemez.

\section{Sonuç}

İnsanlık düşünce tarihini, evrensel bir perspektifle ele alıp incelediğimizde şunu gözlemlemiş olacağız ki ilahi ve insani pek çok düşünce sisteminin ana eksenini insanın ve toplumun iyiliği, yararı, mutluluğu oluşturmaktadır. Sosyal bir varlık olan ve fitratı gereği ihtiyaç duyduğu ve karşılanması gereken pek çok ihtiyacı bulunan insanoğlu, bu gereksinimlerini en iyi ve üst düzeyde ancak sosyal bir çevrede elde edebilir. Bu realiteyi göz önünde bulunduran düşünür ve araştırmacılar, insanların mutluluğu elde etmeleri için oluşturdukları sistem ve siyasal kuramlarını bu doğrultuda organize etmişlerdir. Bu vesile ile insanlık düşünce tarihinde çıkış noktası, yöntemi, araçları farklı da olsa, amacı insanı mutlu etmek olan birbirinden değerli teori, siyasal kuram, siyasi ve ahlaki öğreti oluşturulmuştur. Siyaset ve ahlak felsefesi de iyi hayat, mutlu yaşam, ortak iyiyi amaçlayan ve bu düzlemde araştırma ve irdeleme yapan düşünce alanlarındandır.

\footnotetext{
Yayınları, 2005, 311; İlhan Kutluer, “Müsavat”, Türkiye Diyanet Vakfi İslam Ansiklopedisi, İstanbul: TDV Yayınları, 2006, 32/ 76; Heywood, Siyasetin Temel Kavramlar, 174; Akalın, "Eşitlik", Türkçe Sözlük, 657. 79 Nigel, Warburton. Felsefeye Giriş. çev. Ahmet Cevizci, İstanbul: Paradigma Yayınları, Ekim 2000, 76.
} 
Siyaset felsefesinin, mutlu yaşam için birey devlet ilişkisi, devletin amacı, kaynağı, devletin ödevleri, devlet başkanında olması gereken vasıflar, özgürlük adalet, eşitlik gibi konuları çalışma alanı olarak seçmiş bir felsefe dalı olduğunu gördük. Siyaset felsefesinde bireyin mutluluğu için asli unsur olma özelliği taşıyan temel ilkeler vardır. İyi yaşam, eşitlik, özgürlük, adalet, yasa, erdemli lider, nitelikli bir sivil toplum, hukuk, hak anlayışı, sistemli ve ilkeli işleyen bürokrasi gibi temel ilkeler siyaset felsefesinin ana temalarındandır. İnsanın nitelikli ve mutlu bir hayat sürmesi ve bu huzurlu yaşamın daimi olabilmesi için sıraladığımız temel ilkelerin erdemli bir lider veya siyasal yönetim anlayışı tarafından, bireyin ve toplumun faydasına olacak şekilde pratikte uygulanması gerekmektedir. Böyle olduğu takdirde toplumsal bir mutluluk anlayışı ve yaşamı elde edilebilir.

Değişen zaman ve şartlara uygun bir şekilde farklı yönetim biçimleri ve geçmişin irdelenmesi sonucu elde edilen tecrübe ile olması gereken yönetim anlayışları ve moral değerlere sahip siyasal yönetim ve ahlaki değerlerin egemenliğinde bir siyaset anlayışının arzulanan ve istenen toplumsal mutluluk anlayışına büyük katkısı olacaktır.

\section{KAYNAKÇA}

Akarsu, Bedia. Felsefe Terimleri Sözlüğ̈̈̈. İstanbul: İnkılap Kitabevi, 1994.

Aristoteles. Politika. çev. Furkan Akderin, İstanbul: Say Yayınları, 1280a,101, 2013.

Arnhart, Larry. Siyasi Düşünce Tarihi. çev. Ahmet Kemal Bayram, Ankara: Adres Yayınları, 2004.

Arslan, Ahmet. Felsefeye Giriş, Ankara: Vadi Yayınları, 1996.

Aybakan, Bilal - İbrahim Kâfi Dönmez, "Meşru”, Türkiye Diyanet Vakfı İslam Ansiklopedisi ,29/378-383, Ankara: TDV Yayınları, 2004.

Aydın, Mehmet. "Ahlak", Türkiye Diyanet Vakfı İslam Ansiklopedisi, 2/10-14, İstanbul: TDV Yayınları, 1989.

Barry, Norman P. Modern Siyaset Teorisi, çev. Mustafa Erdoğan-Yusuf Şahin, Ankara: Liberte Yayınları, 2012.

Bayraklı, Bayraktar. Fârâbi'de Devlet Felsefesi. İstanbul: Doğuş Yayınları, 1983.

Bolay, Süleyman Hayri. Felsefi Doktrinler ve Terimler Sözlüğü, Ankara: Akçă̆ Yayınları, 1996.

Bolay, Süleyman Hayri. Felsefeye Giriş, Ankara: Akçağ Yayınları, 2002.

Can, Nevzat. Siyaset Felsefesi Problemleri, Ankara: Elis Yayınları, 2005. 
Cevizci, Ahmet. Paradigma Felsefe Sözlü̆g̈̈, Ankara: Ekin Yayınları, 1996.

Çağrıcı, Mustafa, “Hak”, Türkiye Diyanet Vakfı İslam Ansiklopedisi, 15/137-139, İstanbul: TDV Yayınları, 1997.

Çağrıc1, Mustafa. "Adalet", Türkiye Diyanet Vakfı İslam Ansiklopedisi, 1/341-343, İstanbul: TDV Yayınları, 1988.

Çam, Esat. Siyaset Bilimine Giriş, İstanbul: Güryay Matbaacılık, 1977.

Çüçen, Abdülkadir. Felsefeye Giriş, İstanbul: Asa Yayınları, 2001.

Durmuş, İsmail. “İktidar”, Türkiye Diyanet Vakfı İslam Ansiklopedisi, 22/56, İstanbul: TDV Yayınları, 2000.

Dursun, Davut. Siyaset Bilimi, İstanbul: Beta Yayıncılık, 2002.

Fârâbi, Muhammed b. Tarhan b. Uzluğ. KitabTahsilu's-saade, Haydarabad, H.1345.

Gardet, Louis. Müslüman Site, Toplumsal ve Siyasi Hayat, çev. Ahmet Arslan, İstanbul: Ayrıntı Yayınları, 2014.

Gedikli, Fethi. "Yasa", Türkiye Diyanet Vakfi İslam Ansiklopedisi, 43/336-340, İstanbul: TDV Yayınları, 2013.

Gewırth, Alan. Siyaset Felsefesi, çev. Ahmet Kesgin, Ankara Üniversitesi İlahiyat Fakültesi Dergisi, 52/1 (2011), 349-379.

Gökberk, Macit. Felsefe Tarihi, İstanbul: Remzi Kitabevi, 1996.

Heywood, Andrew. Siyaset Teorisine Giriş, çev. Hızır Murat Köse, İstanbul: Küre Yayınları, 2011.

Heywood, Andrew. Siyasetin Temel Kavramları, çev. Hayrettin Özler, Ankara: Adres Yayınları,

1. Basım, 2012.

İbn Manzur, Muhammed b. Mükerrem. Lisanü'l-Arab, 15 Cilt, Beyrut- Lübnan: Der Sadır, 1990.

İmam Gazali, İhyau Ulumi'd Din, çev. Ahmed Serdaroğlu, 1/ İstanbul: Bedir Yayınevi, 1974.

Kapani, Münci. Politika Bilimine Giriş, Ankara: Bilgi Yayınevi, 2002.

Kaya, Mahmut. “Felsefe”, Türkiye Diyanet Vakfı İslam Ansiklopedisi, 12/311-319, İstanbul: TVD Yayınları, 1995.

Kışlalı, Ahmet Taner. Siyaset Bilimi, Ankara: AÜ Basın Yayın Yüksek Okulu Yayınları, 1987.

Korkut, Şenol. Farabi'nin Siyaset Felsefesi, Ankara: Atlas Yayınları, 1.Basım, 2015.

Köse, Hizır Murat.“Siyaset”, Türkiye Diyanet Vakfi İslam Ansiklopedisi, 37/294-299, İstanbul: TDV Yayınları, 2009.

Kurtoğlu, Zerrin. İslam Düşüncesinin Siyasal Ufku, İstanbul: İletişim Yayınları, 1999. 
Kutluer, İlhan, "Müsavat", Türkiye Diyanet Vakfı İslam Ansiklopedisi, 32/76-79, İstanbul: TDV Yayınları, 2006.

Özden-Elmalı, H.Ömer-Osman. İlkçağ Felsefesi Tarihi, İstanbul: Bilge Kültür Sanat Yayıncılık, 2018.

Özden, H.Ömer. İslam Felsefesi Tarihi, İstanbul: Bilge Kültür Sanat Yayıncılık, 2017.

Öztekin, Ali. Siyaset Bilimine Giriş, Ankara: Siyasal Kitabevi, 2003.

Polat, Selahaddin.“Ferd”, Türkiye Diyanet Vakfi İslam Ansiklopedisi,12/368-369, İstanbul: TDV Yayınları, 1995.

Raynaud Philippe - Stephane Rials, Siyaset Felsefesi Sözlüğ̈̈, çev. İsmail Yerguz, vd. İstanbul: İletişim Yayınları, 2003.

Straus, Leo. "Siyaset Felsefesi Nedir?" Siyasi Hermenötik, çev. Burhanettin Tatar, Samsun: 2000.

Thılly, Frank. Felsefe Tarihi, çev. İbrahim Şener, İstanbul: 1995.

Toku, Neşet. Siyaset Felsefesine Giriş, İstanbul: Kaknüs Yayınları, 2005.

Toku, Neşet. Johne Locke ve Siyaset Felsefesi, Ankara: Liberte Yayınları, 2003.

Ulaş, Sarp Erk. Felsefe Sözlü̆̆̈̈, Ankara: Bilim ve Sanat Yayınları, 2002.

Urhan, Veli. "Siyaset Felsefesinde Adalet, Eşitlik, Özgürlük". Kaygı Uludă̆ Üniversitesi FenEdebiyat Fakültesi Felsefe Dergisi, 26/Bahar (2016), 103-119.

Warburton, Nigel. Felsefeye Giriş, çev. Ahmet Cevizci, İstanbul: Paradigma Yayınları, Ekim, 2000.

Weber, Alfred. Felsefe Tarihi, çev. H.Vehbi Eralp, İstanbul: Sosyal Yayınları, 1991.

Yayla, Atilla. Siyaset Teorisine Giriş, Ankara: Siyasal Yayınevi, 2004. 
